\title{
Synthesis of chalcone-containing zinc and cobalt metallophthalocyanines; investigation of their photochemical, DPPH radical scavenging and metal chelating characters
}

\author{
Arif Baran $\oplus^{1^{*}}$, Emel Karakılıç $\oplus^{1}$, Özlem Faiz $\oplus^{2}$ and Furkan Özen $\oplus^{1}$ \\ ${ }^{1}$ Department of Chemistry, Faculty of Arts and Sciences, Sakarya University, \\ 54187, Sakarya, Türkiye \\ ${ }^{2}$ Department of Chemistry, Faculty of Arts and Sciences, ${ }^{2}$ RTE University \\ 53100, Rize, Türkiye
}

(Received May 02, 2020; Revised June 16, 2020; Accepted June 20, 2020)

\begin{abstract}
In this study, two new phthalocyanines $(\mathrm{M}=\mathrm{Zn}$ and $\mathrm{Co})$ were synthesized using the $(E)-4-(4-(3-(4-$ (benzyloxy)phenyl)acryloyl)phenoxy)phthalonitrile (3) as ligand prepared from the chemical reaction of 4nitrophthalonitrile with (E)-3-(4-(benzyloxy)phenyl)-1-(4-hydroxyphenyl)prop-2-en-1-one (2). All compounds were characterized using by ${ }^{1} \mathrm{H}-\mathrm{NMR},{ }^{13} \mathrm{C}-\mathrm{NMR}$, UV-Vis, FT-IR, and MALDI-TOF mass spectra. Singlet oxygen quantum yields of the synthesized compounds, aggregates in different solutions, metal chelating and 2,2Diphenyl-1-picrylhydrazyl (DPPH) radical scavenging properties were reported.
\end{abstract}

Keywords: Phthalocyanines; photochemical studies; singlet oxygen; quantum yields; metal chelating; DPPH radical scavenging. ( 2020 ACG Publication. All right reserved.

\section{Introduction}

Phthalocyanines (Pcs) and Metallophthalocyanines (MPcs) have been studied for a wide range of applications in view of their distinct and unique optical, spectroscopic, electronic, electrochemical, and thermal properties. ${ }^{1-3}$ The presence of diamagnetic metals in phthalocyanines (such as zinc, aluminum, silicon) makes them a useful photosensitizers in photodynamic therapy (PDT) with their high quantum yields and long triplet lifetime. ${ }^{4-7}$ PDT requires the use of photosensitive molecules known as photosensitizers. Photoactivation causes the formation of singlet oxygen, which produces peroxidative reactions that can cause cell damage and death. ${ }^{8}$ In the earlier studies, hematoporphyrin derivatives and porfimer sodium (photofrin) were succesfully used in PDT and, many secondgeneration photosensitizer, phorphirines and derivatives, have been synthesized for this purpose. ${ }^{9,10}$

The ligands prepared via Claisen-Schmidt condensation are known as chalcones which are belonging to the flavonoid family. ${ }^{11-12}$ Chalcones are aromatic pigments with antioxidant effect on fruits, vegetables and various wounded plant tissues, which act as chemical messenger, physiological regulator and inhibitors of cell cycle. The role of flavonoids against cancer, aging, atherosclerosis, ischemic injury, inflammation and neurodegenerative diseases (Parkinson, Alzheimer) have been reported $^{13-14}$. Their antioxidant, anti-tumor, anti-inflammatory and antiviral activities were seriously discussed in the literature. ${ }^{13-19}$ In addition, dissolution force of chalcone-based ligands in organic solvents increased the interest in chalcone-fused phthalocyanines.

\footnotetext{
* Correspinding author: E-mail: abaran@ sakarya.edu.tr 
Regarding to those properties, synthesis of chalcone-containing zinc and cobalt metallophthalocyanines and their photochemical properties, DPPH radical scavenging and metal chelating capacities were reported herein.

\section{Experimental}

\subsection{General}

Benzyl chloride (Sigma-Aldrich, reagent plus(R), 99\%), 4-hydroxybenzaldehyde (SigmaAldrich, 98\%), 4-hydroxyacetophenone (Sigma-Aldrich, 99\%), 4-nitrophthalonitrile (Sigma-Aldrich, $99 \%$ ), thionyl chloride $\left(\mathrm{SOCl}_{2}\right)$ (Sigma-Aldrich, reagent plus(R), $\left.\geq 99 \%\right)$, potassium carbonate $\left(\mathrm{K}_{2} \mathrm{CO}_{3}\right)$ (Alfa Aesar, anhydrous, 99\%), 1,8-diazabicyclo[5.4.0]undec-7-ene (DBU) (Merck, 98\%), zinc acetate dihydrate $\mathrm{Zn}(\mathrm{OAc})_{2} \cdot 2 \mathrm{H}_{2} \mathrm{O}$ (Sigma-Aldrich, reagent grade), cobalt (II) acetate tetrahydrate $\mathrm{Co}(\mathrm{OAc})_{2} .4 \mathrm{H}_{2} \mathrm{O}$ (Sigma-Aldrich, reagent grade), sodium sulfate $\left(\mathrm{Na}_{2} \mathrm{SO}_{4}\right.$ ) (Alfa Aesar, ACS, $99.0 \%$ min), 2,2',2",2"'-(ethane-1,2-diyldinitrilo)tetraacetic acid (EDTA) (Sigma-Aldrich, $\geq 98.0 \%$ (KT), ferrous chloride $\left(\mathrm{FeCl}_{2}\right)$ (Sigma-Aldrich, reagent plus (R), 98\%) were used as supplied without further purification. Reactions under anhydrous conditions were performed in dried solvents (such as, N,Ndimethylformamide (DMF), dichloromethane (DCM), dimethyl sulfoxide (DMSO), tetrahydrofuran (THF) and ethanol (EtOH)) under argon atmosphere. Silica gel $60(40-63 \mu \mathrm{m}$, Fluka) was used for chromatography. ${ }^{1} \mathrm{H}$ NMR and ${ }^{13} \mathrm{C}$ NMR spectra were recorded in $\mathrm{CDCl}_{3}$ on a VARIAN Infinity Plus $300 \mathrm{MHz}$ NMR spectrometer. Chemical shifts were expressed in ppm relative to $\mathrm{CDCl}_{3}$ (d 7.26 and 77.0 for ${ }^{1} \mathrm{H}$ and ${ }^{13} \mathrm{C}$ NMR, respectively) and Tetramethylsilane (TMS) was as a internal standard. IR spectra were recorded on an Ati Unicam Mattson 1000 Series FT-IR (ATR system) spectrometer. MALDI-TOF spectra were taken on Bruker Daltonics flex Analysis. Electronic absorption spectra were measured on a Shimadzu UV 2600 UV-Vis spectrophotometer

\subsection{Chemistry}

\subsubsection{Synthesis of 4-(benzyloxy)benzaldehyde (1)}

4-Hydroxy benzaldehyde $(1.0 \mathrm{~g}, 8.19 \mathrm{mmol})$ in DMF was added $\mathrm{K}_{2} \mathrm{CO}_{3}(1.130 \mathrm{~g}, 8.19$ $\mathrm{mmol})$. The mixture was stirred at room temperature for $30 \mathrm{~min}$. Benzyl chloride $(1.400 \mathrm{~g}, 8.19 \mathrm{mmol})$ was added dropwise, and the mixture was stirred for $3 \mathrm{~h}$, and the reaction mixture was poured dropwise into ice water $(250 \mathrm{~mL})$ and stirred. The white solid product was filtered and washed with water, dried and recrystallized in ethanol to afford 1. Yield: $1.51 \mathrm{~g}(87 \%)$, m. p.: $69-71^{\circ} \mathrm{C}$. IR $\mathrm{v}_{\max } / \mathrm{cm}^{-}$ 1: $3362 \mathrm{~cm}^{-1}(\mathrm{Ar}-\mathrm{H}) ; 2829 \mathrm{~cm}^{-1}$ (aliphatic $\left.\mathrm{C}-\mathrm{H}\right) ; 1685 \mathrm{~cm}^{-1}(\mathrm{C}=\mathrm{O}) ; 1598,1572,1508 \mathrm{~cm}^{-1}(\mathrm{Ar}-\mathrm{C}=\mathrm{C})$; $1018 \mathrm{~cm}^{-1}$ (C-O-C). ${ }^{1} \mathrm{H}$ NMR (300 MHz, $\left.\mathrm{CDCl}_{3}\right) \delta$ ppm: 9.86 (s, $1 \mathrm{H}, \mathrm{CHO}$ ), 7.82 (quasi d, $\mathrm{H}_{2}$ and $\mathrm{H}_{6}$, $2 \mathrm{H}, J=9.0 \mathrm{~Hz}$ ), 7.15 (quasi d, $\mathrm{H}_{3}$ and $\mathrm{H}_{5}, 2 \mathrm{H}, J=9.0 \mathrm{~Hz}$ ), $7.48-7.32(\mathrm{~m}, 5 \mathrm{H}, \mathrm{Ph}), 5.12(\mathrm{~s}, 2 \mathrm{H}$, $\mathrm{PhCH}_{2} \mathrm{O}$ ). ${ }^{13} \mathrm{C}$ NMR $\left(75 \mathrm{MHz}, \mathrm{CDCl}_{3}\right) \delta \mathrm{ppm}: 190.77,163.62,135.85,131.93,129.96,128.65$, 128.26, 127.44, 115.04, 70.13.

\subsubsection{Synthesis of (E)-3-(4-(benzyloxy)phenyl)-1-(4-hydroxyphenyl)prop-2-en-1-one (2)}

Compound 2 was prepared according to the method reported in the literature. ${ }^{20}$ 4(Benzyloxy)benzaldehyde $(0.500 \mathrm{~g}, 2.36 \mathrm{mmol})$ and 4-hydroxyacetophenone $(0.321 \mathrm{~g}, 2.36 \mathrm{mmol})$ were mixed in ethanol, and then thionyl chloride $(0.5 \mathrm{~mL})$ was added After stirring for $14 \mathrm{~h}$, the mixture was added to water. The product was filtered and washed with cold ethanol to afford compound 2 as yellow crystal. Yield: $0.69 \mathrm{~g}(89 \%)$, m. p.: $187-189{ }^{\circ} \mathrm{C}$. IR $v_{\max } / \mathrm{cm}^{-1}: 3059 \mathrm{~cm}^{-1}(\mathrm{OH})$; $3049 \mathrm{~cm}^{-1}(\mathrm{Ar}-\mathrm{H}) ; 2849 \mathrm{~cm}^{-1}$ (aliphatic C-H); $1641 \mathrm{~cm}^{-1}(\mathrm{C}=\mathrm{O}) ; 1597,1586 \mathrm{~cm}^{-1}(\mathrm{Ar}-\mathrm{C}=\mathrm{C}) ; 1037$ (C-O-C). ${ }^{1} \mathrm{H}$ NMR (300 MHz, $\left.\mathrm{CDCl}_{3} / \mathrm{CD}_{3} \mathrm{OD}: 5 / 1\right) \delta \mathrm{ppm}: 7.97$ (quasi d, 2H, $\mathrm{H}_{2}{ }^{\prime}$ and $\mathrm{H}_{6}{ }^{\prime}, J=9.0$ $\mathrm{Hz}$ ), $7.76\left(\mathrm{~d}, \mathrm{CH}=\mathrm{CH}-\mathrm{CHO}, 1 \mathrm{H}, \mathrm{J}=15 \mathrm{~Hz}\right.$ ), 7.62 (quasi d, $2 \mathrm{H}, \mathrm{H}_{2} "$ and $\mathrm{H}_{6}{ }^{\prime \prime} J=9.0 \mathrm{~Hz}$ ), $7.10(\mathrm{~d}, 2 \mathrm{H}$, $\mathrm{H}_{3}$ 'and $\left.\mathrm{H}_{5}{ }^{\prime}, J=9.0 \mathrm{~Hz}\right), 6.92\left(\mathrm{~d}, 2 \mathrm{H}, \mathrm{H}_{3} "\right.$ and $\left.\mathrm{H}_{5}{ }^{\prime \prime}, J=9.0 \mathrm{~Hz}\right), 5.12\left(\mathrm{~s}, 2 \mathrm{H}, \mathrm{PhCH}_{2} \mathrm{O}\right) .{ }^{13} \mathrm{C}$ NMR $(75$ 
$\left.\mathrm{MHz}, \mathrm{CDCl}_{3} / \mathrm{CD}_{3} \mathrm{OD}: 5 / 1\right) \delta$ ppm: $189.48,161.57,160.68,143.96,136.38,131.10,130.20,128.69$, $128.20,127.96,127.54,119.63,115.44(2 \mathrm{C}), 115.24,70.11$.

\subsubsection{Synthesis of (E)-4-(4-(3-(4-(benzyloxy)phenyl)acryloyl)phenoxy)phthalonitrile (3)}

A mixture of 4-nitrophthalonitrile $(0.6 \mathrm{~g}, 3.45 \mathrm{mmol})$ and (E)-3-(4-(benzyloxy)phenyl)-1-(4hydroxyphenyl)prop-2-en-1-one (2) $(1.14 \mathrm{~g}, 3.45 \mathrm{mmol})$ in $25 \mathrm{~mL}$ of dry DMF was stirred at $50{ }^{\circ} \mathrm{C}$ under $\mathrm{N}_{2}$. Anhydrous $\mathrm{K}_{2} \mathrm{CO}_{3}(0.57 \mathrm{~g}, 4.14 \mathrm{mmol})$ was added to the mixture for over a period of $1.5 \mathrm{~h}$. After stirring the reaction mixture for a further $24 \mathrm{~h}$, the undissolved salt was removed by filtration. The reaction mixture was added dropwise into ice water $(250 \mathrm{~mL})$. The organic phase was extracted with DCM $(250 \mathrm{~mL})$ and dried on $\mathrm{Na}_{2} \mathrm{SO}_{4}$. After evaporation of the solution under reduced pressure gave yellow residue. The residue was purified by silica gel column chromatography to afford 3 . Yield: $1.20 \mathrm{~g}(76 \%)$, m. p.: $198{ }^{\circ} \mathrm{C}$. IR $\mathrm{v}_{\max } / \mathrm{cm}^{-1}: 3073 \mathrm{~cm}^{-1}(\mathrm{Ar}-\mathrm{H}) ; 2949 \mathrm{~cm}^{-1}$ (aliphatic C-H); $2230 \mathrm{~cm}^{-1}$ $(\mathrm{C} \equiv \mathrm{N}) ; 1655 \mathrm{~cm}^{-1}(\mathrm{C}=\mathrm{O}) ; 1588,1575,1508 \mathrm{~cm}^{-1}(\mathrm{C}=\mathrm{C}) ; 1025 \mathrm{~cm}^{-1}$ (C-O-C). ${ }^{1} \mathrm{H}$ NMR $(300 \mathrm{MHz}$, $\mathrm{CDCl}_{3}$ ) $\delta$ ppm: 8.19 (quasi d, $2 \mathrm{H}, \mathrm{H}_{3}{ }^{\prime}$ and $\mathrm{H}_{5}{ }^{\prime} J=9.0 \mathrm{~Hz}$ ), $7.84\left(\mathrm{~d}, 1 \mathrm{H}, \mathrm{H}_{3}{ }^{\prime \prime}, \mathrm{J}=15 \mathrm{~Hz}\right.$ ), 7.78 (overlapped $2 \mathrm{H}), 7.51-7.23(\mathrm{~m}, 9 \mathrm{ArH}), 7.20\left(\mathrm{~d}, 2 \mathrm{H}, \mathrm{H}_{2} "\right.$ and $\left.\mathrm{H}_{6} " J=9.0 \mathrm{~Hz}\right), 7.03\left(\mathrm{~d}, 2 \mathrm{H}, \mathrm{H}_{3} "\right.$ and $\mathrm{H}_{5} ", J=$ 9.0Hz), 5.13 (s, $2 \mathrm{H}, \mathrm{PhOCH}_{2}$ ). ${ }^{13} \mathrm{C}$ NMR $\left(75 \mathrm{MHz}, \mathrm{CDCl}_{3}\right.$ ) $\delta \mathrm{ppm}: 188.97,161.29,160.86,157.35$, $145.58,136.50,135.85,131.46,130.67,128.95,128.48,127.77,122.59,122.41,120.38,119.26$, $118.11,115.58,115.06,110.06,70.36$.

\subsubsection{General Procedure for Preparation of the Synthesis of zinc (II) phthalocyanine (4a)}

A mixture of $3(0.1 \mathrm{~g}, 0.22 \mathrm{mmol}), \mathrm{Zn}(\mathrm{OAc})_{2} .2 \mathrm{H}_{2} \mathrm{O}(0.058 \mathrm{~g}, 0.26 \mathrm{mmol})$ and 2-3 drops 1.8diazabisiklo[5.4.0] undek-7-en (DBU) were stirred at $130{ }^{\circ} \mathrm{C}$ in dry DMF under $\mathrm{N}_{2}$ for $24 \mathrm{~h}$. The reaction mixture was cooled to rt and undissolved salt was removed by filtration. The dark green solution was poured into ice-water $(100 \mathrm{~mL})$ and stirred for $1 \mathrm{~h}$ and filtered. The filtrates were washed with a plenty of water then hot ethanol and removed of the unreacted organic materials. The product was dried in the oven to give a crude 4a which is soluble DCM, THF, DMF and DMSO. Then the it was purified using column chromatography on silica gel. The chromatography was repeated and various solution ratios (DCM / THF, DCM / EtOH, THF / EtOH) were used. All purified fractions were collected to give compound $4 \mathbf{a}$ as green solid. Yield: $0.05 \mathrm{~g}(43 \%)$, m. p.: $>350{ }^{\circ} \mathrm{C}$. IR $v_{\max } / \mathrm{cm}^{-1}$ : $3063 \mathrm{~cm}^{-1}(\mathrm{Ar}-\mathrm{H}) ; 2958 \mathrm{~cm}^{-1}$ (aliphatic $\left.\mathrm{C}-\mathrm{H}\right) ; 1657 \mathrm{~cm}^{-1}(\mathrm{C}=\mathrm{O}) ; 1594,1574,1505 \mathrm{~cm}^{-1}(\mathrm{C}=\mathrm{N}, \mathrm{C}=\mathrm{C})$; $1025 \mathrm{~cm}^{-1}$ (C-O-C). UV-Vis (DMF), $\lambda_{\max }, \mathrm{nm}: 679.5,618,354.5$. MALDI-TOF MS: $\mathrm{m} / z[\mathrm{M}]^{+}$calcd. for $\mathrm{C}_{120} \mathrm{H}_{80} \mathrm{~N}_{8} \mathrm{O}_{12} \mathrm{Zn}$ : 1891.38 ; found $[\mathrm{M}+\mathrm{H}]^{+}$1891.17. Elemental analysis for $\left[\mathrm{C}_{120} \mathrm{H}_{80} \mathrm{~N}_{8} \mathrm{O}_{12} \mathrm{Zn}\right]$ : C, 76.20; H, 4.26; N, 5.92. Found: C, 76.28; H,4.32; N, 5.99\%.

\subsubsection{General Procedure for Preparation of the Synthesis of Cobalt (II) phthalocyanine (4b)}

A mixture of $3(0.1 \mathrm{~g}, 0.22 \mathrm{mmol}), \mathrm{Co}(\mathrm{OAc})_{2} .4 \mathrm{H}_{2} \mathrm{O}(0.065 \mathrm{~g}, 0.26 \mathrm{mmol})$ and 2-3 drops 1.8diazabisiklo[5.4.0]undek-7-en (DBU) were stirred at $130{ }^{\circ} \mathrm{C}$ of dry DMF under $\mathrm{N}_{2}$ for $24 \mathrm{~h}$. The reaction mixture was cooled down to room temperature. The undissolved salt was removed by filtration. After the dark green product was poured into ice-water $(100 \mathrm{~mL})$ and stirred. It was filtered and washed with water, hot ethanol, remove the unreacted organic materials. The resulting dark green product was dried in an oven. This compound is readily soluble DCM, THF, DMF and DMSO. Then the dark green residue was purified using column chromatography on silica gel. The chromatography were repeated with various solution ratios (DCM / THF, DCM / EtOH, THF / EtOH). All purified fractions were collected to afford $\mathbf{4 b}$ as green solid. Yield: $0.06 \mathrm{~g}(53 \%)$, m. p.: $>350{ }^{\circ} \mathrm{C}$. IR $v_{\max } / \mathrm{cm}^{-1}$ : $3066 \mathrm{~cm}^{-1}(\mathrm{Ar}-\mathrm{H}) ; 2930 \mathrm{~cm}^{-1}$ (aliphatic $\left.\mathrm{C}-\mathrm{H}\right) ; 1656 \mathrm{~cm}^{-1}(\mathrm{C}=\mathrm{O}) ; 1592,1556,1507 \mathrm{~cm}^{-1}(\mathrm{C}=\mathrm{N}, \mathrm{C}=\mathrm{C})$; $1025 \mathrm{~cm}^{-1}$ (C-O-C). UV-Vis (DMF), $\lambda_{\max }, \mathrm{nm}: 667.5,602.5,345.5$. MALDI-TOF MS: $m / z[\mathrm{M}]^{+}$calcd. for $\mathrm{C}_{120} \mathrm{H}_{80} \mathrm{~N}_{8} \mathrm{O}_{12} \mathrm{Co}$ : 1884.94; found $[\mathrm{M}+\mathrm{H}]^{+}$1884.78. Elemental analysis for $\left[\mathrm{C}_{120} \mathrm{H}_{80} \mathrm{~N}_{8} \mathrm{O}_{12} \mathrm{Co}\right]$ : $\mathrm{C}$, 76.47; H, 4.28; N, 5.94. Found: C, 76.55; H,4.25; N, 5.92\%. 


\subsection{Metal Ions Chelating Effects Assay}

Metal chelating activities of the phthalocyanines were examined using ferrous ion-ferrozine complex method. Results were compared to EDTA, which was used as a reference compound. $500 \mu \mathrm{L}$ of varying concentrations $(25-100 \mu \mathrm{M})$ of phthalocyanine was prepared and added to $2 \mathrm{mM}, 50 \mu \mathrm{L}$ $\mathrm{FeCl}_{2}$ and $5 \mathrm{mM}, 100 \mu \mathrm{L}$ ferrozine. After 10 minute incubation at room temperature, optical density of the samples was measured at $562 \mathrm{~nm}$. A control assay mixture without phthalocyanine was also studied. All experiments were repeated three times and the results were stated as the mean \pm standard deviation (S.D.). Metal chelating effect was calculated using the equation below..$^{21-28}$

$$
\text { Metal chelating effect (\%): }\left[\left[\mathrm{A}_{\text {control }}-\mathrm{A}_{\text {sample }}\right] / \mathrm{A}_{\text {control }}\right] \times 100
$$

The reduction of DPPH induces the radical to change color (violet to yellow) and this change is quantifiable at $517 \mathrm{~nm}$.

\subsection{DPPH Radical Scavenging Activity Assay}

DPPH radical scavenging activities of Pcs were measured to predict their in vitro antioxidant activities. ${ }^{29-30}$ Briefly, $0.5 \mathrm{~mL}$ of Pcs $\mathbf{4 a}$ and $\mathbf{4 b}$ at different concentrations in DMSO were added to a freshly prepared $1 \mathrm{~mL}$ of $0.1 \mathrm{mM}$ DPPH in methanol. The assay mixtures were incubated in dark for 50 minutes, at room temperature. Their optical density of the assay mixtures was measured at $517 \mathrm{~nm}$. A control without Pcs and a gallic acid standard was studied at the same conditions. All experiments were repeated three times and the results were stated as the mean \pm standard deviation (S.D.). Free radical scavenging effect of Pcs was calculated using the equation (3).

\subsection{Singlet Oxygen Measurements}

The compound with singlet oxygen quencher was irradiated in the $\mathrm{Q}$ band region using photoirradiation apparatus. ${ }^{31}$ Quantum yields $\Phi_{\Delta}$ for singlet oxygen were performed according to relative method $\mathrm{ZnPc}$ in DMSO. DPBF (1,3-diphenylisobenzofuran) was used as a chemical quencher. The experimental part was performed in DMSO. To a solution of $\mathbf{4 a}$ was added a singlet oxygen quencher $\left(3 \times 10^{-5} \mathrm{~mol} / \mathrm{dm}^{-3}\right)$ and the intensity of light was applied as $8.15 \times 10^{15}$ photon s$~^{-1} \mathrm{~cm}^{-2}$ Eq. (2). ${ }^{32}$

$$
\Phi_{\Delta}=\Phi_{\Delta}^{\mathrm{Std}} \frac{\mathrm{R} \cdot I_{\mathrm{abs}}^{\mathrm{Std}}}{\mathrm{R}^{\mathrm{Std}} \cdot I_{\mathrm{abs}}}
$$

Where,

$\Phi_{\Delta}^{\text {Std }}$ defines the singlet oxygen quantum yield $\left(\Phi_{\Delta}\right)$ for the standard Zn-Pc $\left(\Phi_{\Delta}^{\text {Std }}=0.67\right.$ in DMSO $)$.

$R$ and $R^{S t d}$ are DPBF photo-bleaching properties in the presence of $\mathbf{4 a}$.

$I_{a b s}$ and $I_{\mathrm{abs}}^{\mathrm{Std}}$ are the rate of light used for samples and standard. ${ }^{33,34}$

\subsection{Photodegradation Measurements}

Photodegradation quantum yield $\left(\Phi_{\mathrm{d}}\right)$ was measured by using Eq. (3), to examin the changes in fluorescence in the course of degradation of the compound exposed to light. During the photodegradation of phthalocyanine compounds, the decrease in $\mathrm{Q}$ band was determined and the trends of the calibration graphs were calculated in specific time intervals. ${ }^{35-36}$ Photodegradation quantum yield $(\Phi \mathrm{d})$ determination was described in the literature. ${ }^{24}$ 


$$
\Phi_{d}=\frac{\left(C_{0}-C_{t}\right) \cdot V \cdot N_{A}}{I_{a b s} \cdot S \cdot t}
$$

Where,

$C_{o}$ and $C_{t}$ are MPc concentrations before and after illumination, respectively,

$V$ is the reaction volume,

$N_{A}$ is Avogadro constant,

$S$ is the irradiated cell,

$t$ is the irradiation time. ${ }^{37}$

\section{Result and Discussion}

\subsection{Chemistry}

A metal ion in the core of a metallopytalocyanine could be active as a catalyst/phtolocatalyst. For photocatalytic activities of MPcs, it should contain metal ions, such as Mg (II), Al (III), Si (IV) and $\mathrm{Zn}$ (II), with a closed $\mathrm{p}$ or d electron configuration, resulting in a highly excited state life time. However, metal phthalocyanines with redox active metal ions, like Co (II) and Fe (II), having an open shell structure, show catalytic and electrocatalytic properties. ${ }^{38,39}$

Pcs containing four chalcone groups at peripherals were prepared using zinc (II) and cobalt (II) acetate salts (Scheme 1). The synthesis was initiated by reacting 4-hydroxybenzaldehyde with benzyl chloride in DMF in the presence of potassium carbonate as a base, which yielded 4(benzyloxy)benzaldehyde $\mathbf{1}$ as a sole product in $87 \% .^{40}$ Condensation of $\mathbf{1}$ and 4-hydroxyacetophenone in a mixture of EtOH and $\mathrm{SOCl}_{2}$ gave the conjugated system, (E)-3-(4-(benzyloxy)phenyl)-1-(4hydroxyphenyl)prop-2-en-1-one 2 . $^{20}, 38-41$ Nucleophilic substitution reaction between $\mathbf{2}$ and 4 nitrophthalonitrile was performed in DMF, using potassium carbonate as a base at $50{ }^{\circ} \mathrm{C}$ for 24 hours under nitrogen atmosphere to afford the donor compound $\mathbf{3}$ in $76 \%$ yield. ${ }^{42}$ Syntheses of phthalocyanine derivatives $\mathbf{4 a}$ and $\mathbf{4 b}$ (Scheme 2) were performed at $130{ }^{\circ} \mathrm{C}$, using $\mathrm{Zn}$ and Co metal salts under nitrogen atmosphere in DMF in the presence of DBU as a catalyst. ${ }^{43}$ and achieved in good yields (43 and 53\%).

The selection of metal atoms, i.e. $\mathrm{Zn}$ and $\mathrm{Co}$, was made considering intramolecular donoracceptor interaction between the soluble ligand and the terminal metal valance shells in phthalocyanine complexes. Thus, the final Pcs had good solubility properties obtained through the presence of conjugated systems at the peripherals. They were characterized by using UV-Vis, FT-IR, ${ }^{1} \mathrm{H}$ NMR, ${ }^{13} \mathrm{C}$ NMR, and MALDI-TOF mass spectra.

Details of the structure elucidation of compounds 1-2 was discussed in supporting information file to avoid reputation of the literature.

IR spectra of compound $\mathbf{3}$ (Figure 1, (Figure S13).) demonstrated an aromatic C-H band at 3073 $\mathrm{cm}^{-1}$ and an aliphatic C-H vibration band at $2931 \mathrm{~cm}^{-1}$. A characteristic $\mathrm{C} \equiv \mathrm{N}$-vibration band of phthalonitrile appeared at $2232 \mathrm{~cm}^{-1}$. While a $\mathrm{C}=\mathrm{O}$ band was observed at $1655 \mathrm{~cm}^{-1}$, aromatic $\mathrm{C}=\mathrm{C}$ bands appeared at $1599 \mathrm{~cm}^{-1}$ and $1588 \mathrm{~cm}^{-1}$. Moreover, a band between $1140-1242 \mathrm{~cm}^{-1}$ was attributed to C-O-C moiety.<smiles>N#Cc1ccc(Oc2ccc(C(=O)C=Cc3ccc(OCc4ccccc4)cc3)cc2)cc1C#N</smiles>

Figure 1. (E)-4-(4-(3-(4-(benzyloxy)phenyl)acryloyl)phenoxy)phthalonitrile 3

Regarding the ${ }^{1} \mathrm{H}$ NMR of the compound 3, while $\mathrm{H}_{3}{ }^{\prime} / \mathrm{H}_{5}{ }^{\prime}$ resonated as an $\mathrm{AA}^{\prime}$ part of $\mathrm{AA}^{\prime} \mathrm{BB}^{\prime}$ system giving quasi doublet at $8.19 \mathrm{ppm}, \mathrm{H}_{3}$ " resonated by giving doublet $(J=15.0 \mathrm{~Hz})$ at $7.84 \mathrm{ppm}$ 
overlapping with $\mathrm{H}_{6}$ at $7.80 \mathrm{ppm} . \mathrm{H}_{2}{ }^{\prime \prime} / \mathrm{H}_{6}$ " were seen as $\mathrm{AA}^{\prime}$ part of $\mathrm{AA}^{\prime} \mathrm{BB}^{\prime}$ system at $7.63 \mathrm{ppm} .5$ ArH of phenyl ring, $\mathrm{H}_{3}, \mathrm{H}_{5}, \mathrm{H}_{2}$ ", resonated as multiplets at 7.55-7.25 ppm $\left(\mathrm{PhCH}_{2} \mathrm{O}\right.$ protons resonated as singlet at $5.19 \mathrm{ppm}$ (Figure S7 and Figure S11). The ${ }^{13} \mathrm{C}$-NMR resonance signals were in agreement with structure (Figure S8-S10).

Although zinc phthalocyanine 4a looked soluble in common organic solvents, its NMR measurements could not be performed due to aggregation, leading to broadening of the proton signals. Also, the NMR measurements of the cobalt phthalocyanine $\mathbf{4 b}$ was precluded owing to its paramagnetic nature..$^{20,41}$ In the electronic absorption spectrum, two absorption bands were observed for the phthalocyanine compounds, which are B and Q bands at about 300-450 and 600-700 nm, respectively.

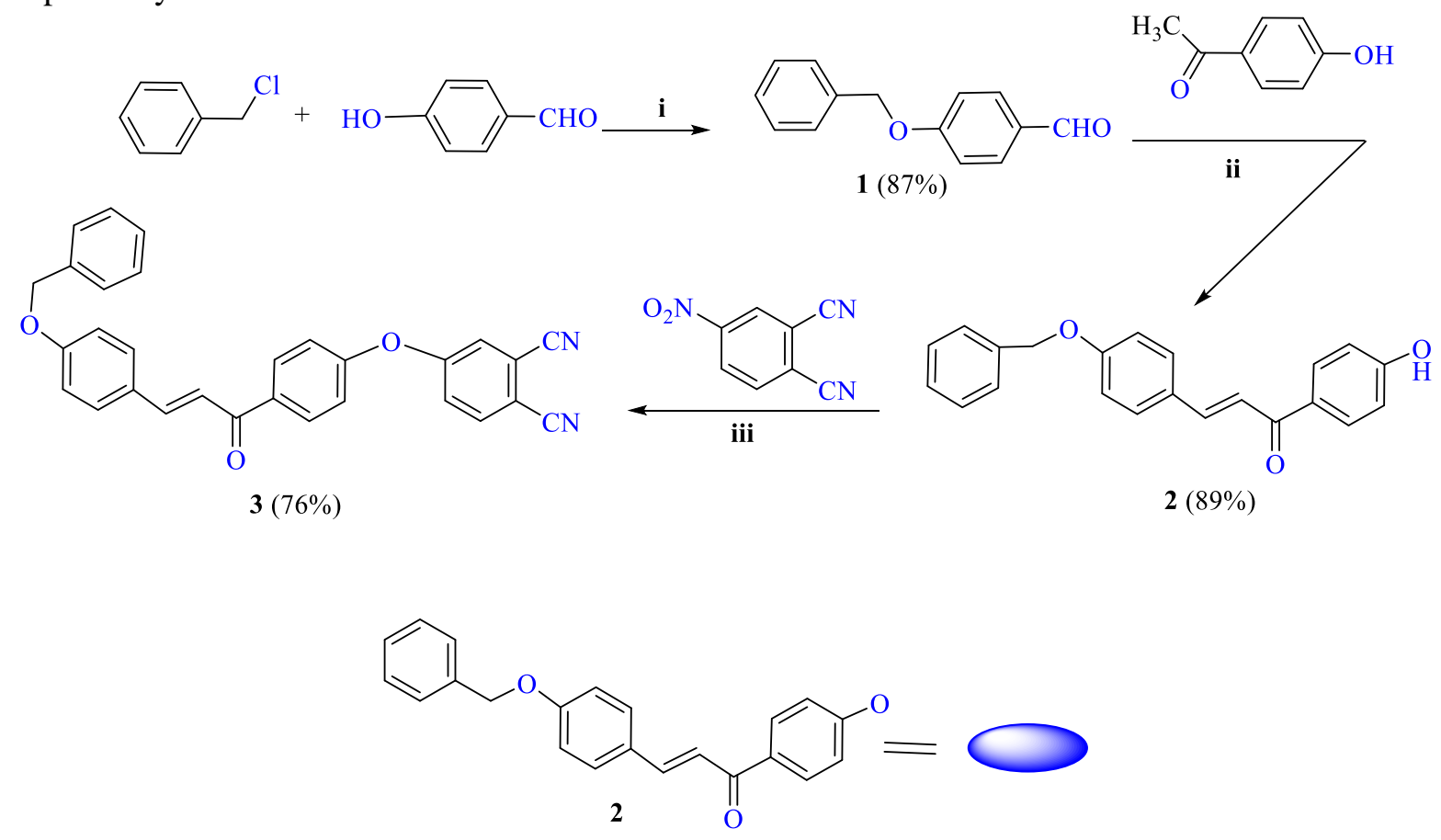

Scheme 1. Synthetic route of compounds 1, 2, 3. (i) $\mathrm{K}_{2} \mathrm{CO}_{3}$, DMF, rt; (ii) $\mathrm{SOCl}_{2}$, EtOH, r.t., $12 \mathrm{~h}$; (iii) $\mathrm{K}_{2} \mathrm{CO}_{3}, \mathrm{DMF}, 50{ }^{\circ} \mathrm{C}$.

The phthalocyanines developed herein are well soluble in different solvents such as dichloromethane (DCM), N,N-dimethylformamide (DMF), tetrahydrofuran (THF) and dimethyl sulfoxide (DMSO). Moreover, they have low aggregation in these solvents and demonstrate characteristic absorption bands, i.e. a B-band between 360-385 $\mathrm{nm}$ and a Q-band band between 580-700 $\mathrm{nm}$ (Figure 4 and Figure 5). The UV-Vis spectra of the phthalocyanine derivatives $\mathbf{4 a}$ and $\mathbf{4 b}$ are good indication for their structures. Regarding the IR peaks of $\mathbf{4 a}$ and $\mathbf{4 b}$ (Figure S16 and Figure S19, respectively), while the characteristic functional group vibration of $-\mathrm{CN}\left(2232 \mathrm{~cm}^{-1}\right)$ were disappeared, appearance of the stretching vibration bands of $\mathrm{C}=\mathrm{O}$ groups at $1594 \mathrm{~cm}^{-1}$ (for $\mathrm{Pc} \mathbf{4 a}$ ), and $1593 \mathrm{~cm}^{-1}$ (for Pc 4b) confirmed both phthalocyanines. The characteristic C-O-C bands at $1162 \mathrm{~cm}^{-1}$ for $\mathbf{4 a}$, and 1213 $\mathrm{cm}^{-1}$ for $\mathbf{4 b}$ are also good indications for the structures. The other weak absorption bands between 3064$2865 \mathrm{~cm}^{-1}$ for $\mathbf{4 a}$, and between $3068-2930 \mathrm{~cm}^{-1}$ for $\mathbf{4 b}$ are the aromatic $=\mathrm{C}-\mathrm{H}$ stretching bands for the substituted phthalocyanines. The mass spectra of phthalocyanine derivatives $\mathbf{4 a}$ and $\mathbf{4 b}$ supported the proposed molecular formula. Molecular ion peaks identified $\mathrm{m} / \mathrm{z}[\mathrm{M}]^{+}$calcd. for $\mathrm{C}_{120} \mathrm{H}_{80} \mathrm{~N}_{8} \mathrm{O}_{12} \mathrm{Zn}$ : 1891.38; found $[\mathrm{M}+\mathrm{H}]^{+} 1891.17$ for 4a (Figure S15) and $\mathrm{m} / z[\mathrm{M}]^{+}$calcd. for $\mathrm{C}_{120} \mathrm{H}_{80} \mathrm{~N}_{8} \mathrm{O}_{12} \mathrm{Co}$ : 1884.94; found $[\mathrm{M}+\mathrm{H}]^{+} 1884.78$ for $\mathbf{4 b}$ (Figure S18). 

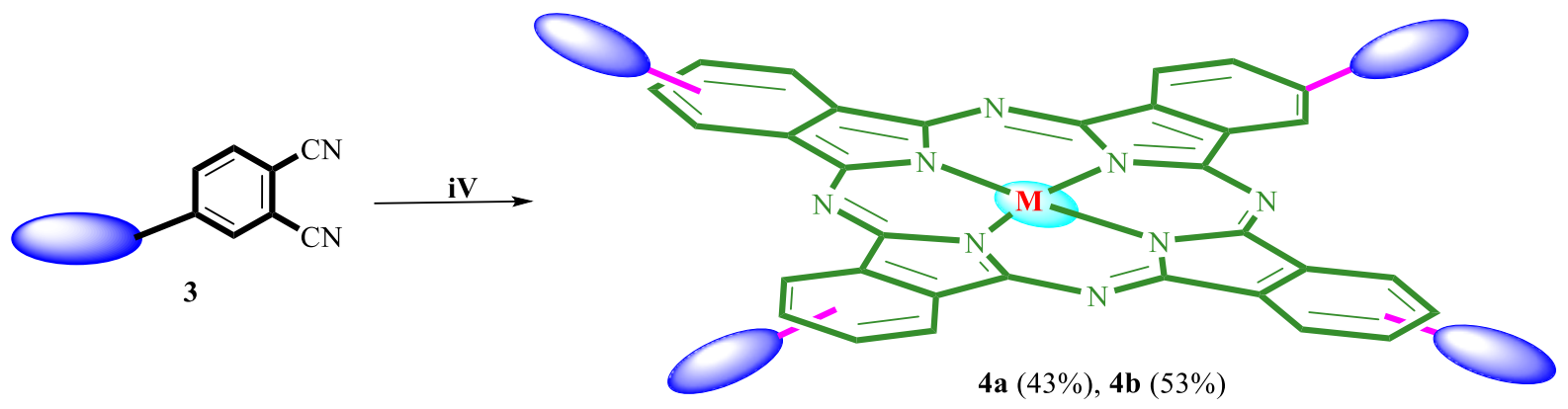

Scheme 2. Synthetic route of compounds $4 \mathbf{a}$ and $\mathbf{4 b}$. $4 \mathbf{a} \mathrm{Zn}(\mathrm{OAc})_{2} \cdot 2 \mathrm{H}_{2} \mathrm{O}$, DMF, $130{ }^{\circ} \mathrm{C}, 24 \mathrm{~h} ; \mathbf{4 b}$ $\mathrm{Co}(\mathrm{OAc})_{2} \cdot 4 \mathrm{H}_{2} \mathrm{O}, \mathrm{DMF}, 130{ }^{\circ} \mathrm{C}, 24 \mathrm{~h}$

UV-Vis spectra of the compounds $\mathbf{4 a}$ and $\mathbf{4 b}$ were recorded in DMSO, DCM and DMF (Figures 2 and 3, respectively). The $\lambda_{\max }$ values for B and Q bands performed in these solutions are given in the Tables 1 and 2 .

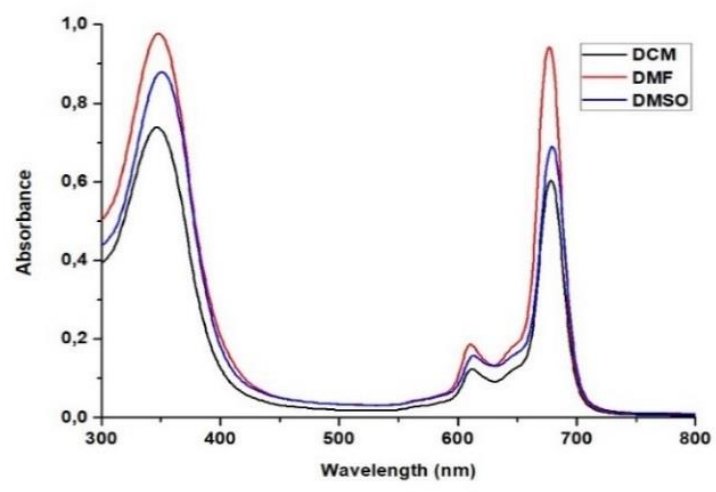

Table 1. The $\lambda_{\max }$ values of $B$ and $Q$ bands for $\mathbf{4 a}$ performed in different solvents

\begin{tabular}{|c|c|c|c|}
\hline Solvent & $\begin{array}{l}\lambda_{\max ,}(\mathbf{n m}) \\
\text { for } B\end{array}$ & $\begin{array}{c}\lambda_{\max ,}(\mathbf{n m}) \text { for } \\
\mathbf{Q}_{1}\end{array}$ & $\begin{array}{c}\lambda_{\max ,}(\mathbf{n m}) \\
\text { for } Q_{2}\end{array}$ \\
\hline DMSO & 354 & 619 & 682.5 \\
\hline DCM & 352.5 & 617.5 & 682 \\
\hline DMF & 354.5 & 618 & 679.5 \\
\hline
\end{tabular}

Figure 2. UV-Vis absorption spectra of: 4 a in different solvents (concentration $=1 \times 10^{-5} \mathrm{M}$ )

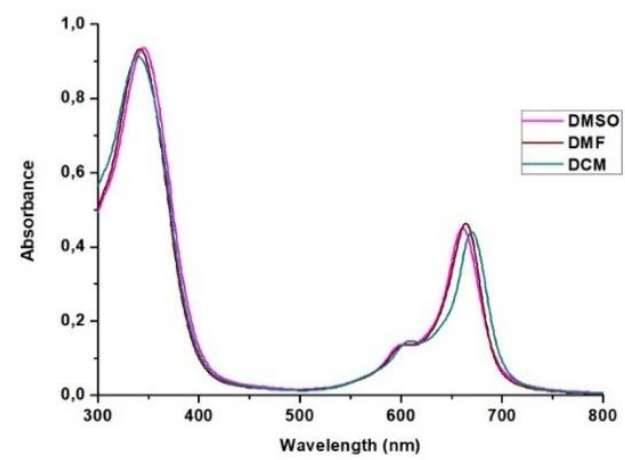

Table 2. The $\lambda_{\max }$ values of $B$ and $Q$ bands for $\mathbf{4 b}$

Figure 3. UV-Vis absorptionspectra of: $\mathbf{4 b}$ in different solvents (concentration $=1 \times 10^{-5} \mathrm{M}$ )

In different concentrations, the compound 4a exhibited a low aggregation. Aggregation behavior of phthalocyanine 4a in different concentrations depends on its skeleton and the solubility of chalcone groups in the peripheral position attached to this skeleton. Aggregation, which is usually exhibited as a coplanar association, varies according to peripheral or non-periperal groups, solutions, concentrations and behaviours of the complexed metal ions. ${ }^{43-46}$ 


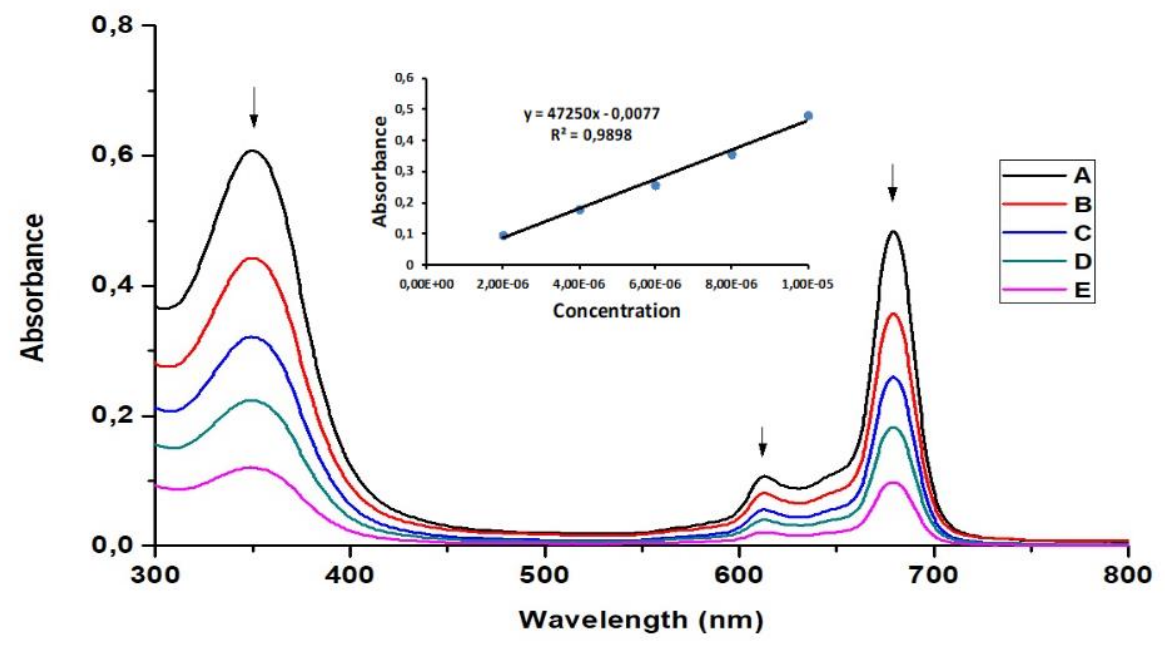

Figure 4. UV-Vis spectra of $\mathrm{ZnPc} 4 \mathrm{a}$ in DMSO at different concentrations: $10 \times 10^{-6}(\mathrm{~A}), 8 \times 10^{-6}(\mathrm{~B})$, $6 \times 10^{-6}(\mathrm{C}), 4 \times 10^{-6}(\mathrm{D}), 8 \times 10^{-6} \mathrm{~mol} \mathrm{dm}{ }^{-3}(\mathrm{E})$. (inset: plot of absorbance versus concentration)

UV spectra of $\mathrm{ZnPc}$ 4a in DMSO at different concentrations were examined for its aggregation behaviours (Figure 4). At lower concentrations (from $5 \times 10^{-6}$ to $1 \times 10^{-6}$ ), the intensity of the Q-band absorbtion were decreased, and a new band did not form due to aggregation. ${ }^{44}$

\subsection{Metal Chelating Effects}

$\mathrm{Fe}^{2+}$ has the ability to remove an electron from a peroxide resulting in the formation of a radical. ${ }^{21-22}$ In order to avoid radicals in metabolism, $\mathrm{Fe}^{2+}$ chelation might be a practicable therapeutic approach. ${ }^{23}$ Divalent iron can quantitatively chelates ferrozine iron yielding a colored complex. The presence of another chelator can block the complex formation. In that case the color is diminished. Measurement of color changes allows the estimation of the chelating capacity of the chelator candidates. ${ }^{23}$ Metal chelating activity of the phthalocyanines were determined at 25, 50, 75 and 100 $\mu \mathrm{M}$ concentrations using their $1 \mathrm{mM}$ stock solutions in DMSO.

Table 3. Ferrous ions chelating activity $(\%)$ of the phthalocyanines

$\mu \mathbf{M}^{\mathbf{a}}$

$\begin{array}{cr}25 & 8.52 \pm 0.18^{\mathrm{b}} \\ 50 & 18.27 \pm 0.22^{\mathrm{b}} \\ 75 & 26.32 \pm 0.17^{\mathrm{b}} \\ 100 & 30.31 \pm 0.31^{\mathrm{b}}\end{array}$

\section{$4 b$} EDTA $^{\mathrm{c}}$

$15.65 \pm 0.15^{\mathrm{b}}$

$51.42 \pm 0.18^{\mathrm{b}}$

$82.31 \pm 0.08^{\mathrm{b}}$

$96.85 \pm 0.21^{\mathrm{b}}$

\footnotetext{
${ }^{a}$ Four experiments were performed for all compounds in each experiment triplicated.

${ }^{\mathrm{b}}$ Mean values $\pm \mathrm{SD}$ are shown for triplicate experiments.

${ }^{\mathrm{c}}$ Reference compound.
}

Table 3 presents ferrous ions chelating activity (\%) of $\mathbf{4 a}$ and $\mathbf{4 b}$. For all studied samples, the chelation activity increased with the increase of their concentrations. 4a was a good chelator and its chelation capacity increased from $8.52 \pm 0.18 \%$ to $30.31 \pm 0.31$. 4a and $\mathbf{4 b}$ showed more or less ferrous ion chelation properties when compared with EDTA. Phthalocyanines with similar and higher metal chelating properties were reported in the literature ${ }^{21-22,24}$ (Figure 5) 


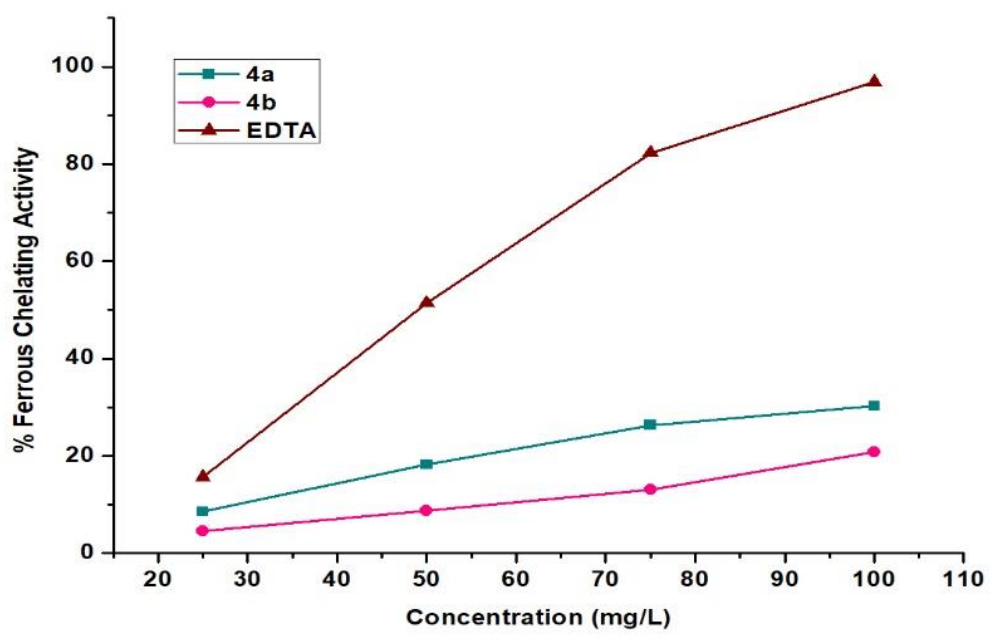

Figure 5. Ferrous chelating activity of $\mathbf{4 a}$ and $\mathbf{4 b}$ complex. The compounds were tested with concentrations ranging from $25 \mu \mathrm{M}$ to $100 \mu \mathrm{M}$. EDTA was used as reference compound

\subsection{DPPH Radical Scavenging Activity}

This method is mainly based on reduction of 1,1-diphenyl-2-picrylhydrazyl (DPPH), which produces an easily identifiable strong violet color. The reduction of DPPH induces the radical to change color (violet to yellow) and this change is $517 \mathrm{~nm} .{ }^{25}$ DPPH radical scavenging assay is frequently used to detect the antioxidant capacity of synthesized compounds or plant extracts. ${ }^{21-22,25-28}$ The ability of Pcs to scavenge DPPH radical were studied using above method. Pcs stock solutions in DMSO were treated with DPPH in methanol. Samples were used at different concentrations ranging from 25 to $100 \mu \mathrm{M}$. DMSO was used as a control. DPPH radical scavenging capacity of Pcs are presented in Table 4. 4a and $\mathbf{4 b}$ exhibited DPPH radical scavenging capacity at studied concentrations (4a: $16.85 \pm 0.32 \%, 23.88 \pm 0.16 \%, 29.74 \pm 0.38 \%, 39.65 \pm 0.34 \%$ and $\mathbf{4 b}: 8.62 \pm 0.27 \%, 14.41 \pm$ $0.37 \%, 29.45 \pm 0.52 \%, 34.99 \pm 0.36 \%)$. The highest antioxidant activity was observed with $4 \mathbf{a}$ complex $25 \mu \mathrm{M}, 50 \mu \mathrm{M}, 75 \mu \mathrm{M}$ and $100 \mu \mathrm{M}$. 4b complex was not as effective as gallic acid ${ }^{24}$ (Figure $6)$.

Table 4. Radical-scavenging activity on DPPH radicals (\%) of the phthalocyanines.

\begin{tabular}{ccrc}
\hline $\boldsymbol{\mu} \mathbf{M}^{\mathbf{a}}$ & $\mathbf{4 a}$ & $\mathbf{4 b}$ & Gallic Acid $^{\mathbf{c}}$ \\
\hline & & & \\
25 & $16.85 \pm 0.32^{\mathrm{b}}$ & $8.62 \pm 0.27^{\mathrm{b}}$ & $68.88 \pm 0.40^{\mathrm{b}}$ \\
50 & $23.88 \pm 0.16^{\mathrm{b}}$ & $14.41 \pm 0.37^{\mathrm{b}}$ & $81.53 \pm 0.42^{\mathrm{b}}$ \\
75 & $29.74 \pm 0.38^{\mathrm{b}}$ & $29.45 \pm 0.52^{\mathrm{b}}$ & $87.71 \pm 038^{\mathrm{b}}$ \\
100 & $39.65 \pm 0.34^{\mathrm{b}}$ & $34.99 \pm 0.36^{\mathrm{b}}$ & $90.58 \pm 0.50^{\mathrm{b}}$ \\
\hline
\end{tabular}

\footnotetext{
${ }^{\mathrm{a}}$ Four experiments were performed for all compounds in each experiment triplicated.

b Mean values \pm SD are shown for triplicate experiments.

${ }^{\mathrm{c}}$ Reference compound.
} 


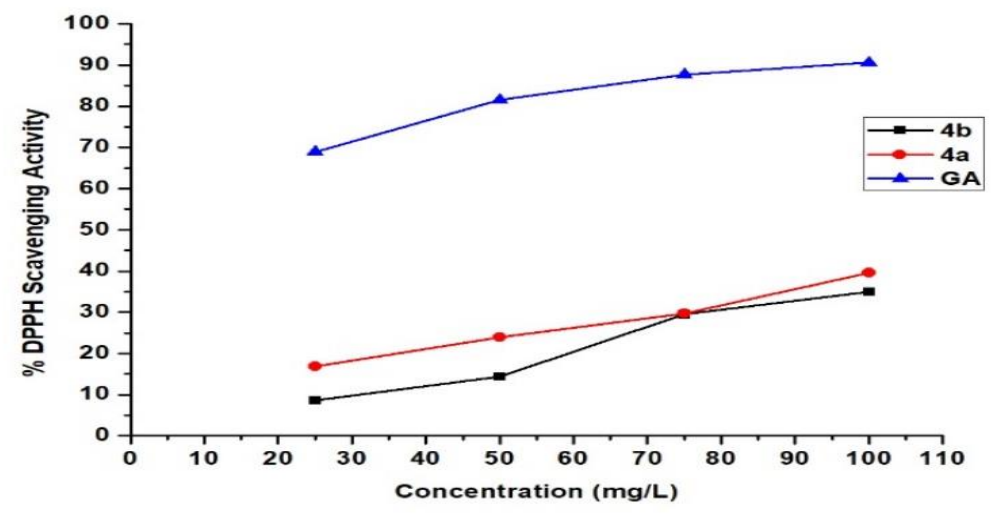

Figure 6. Radical-scavenging activity on DPPH radicals (\%) of $\mathbf{4 a}$ and $\mathbf{4 b}$ complex. The compounds were tested with concentrations ranging from $25 \mu \mathrm{M}$ to $100 \mu \mathrm{M}$. Gallic acid (GA) was used as standard mixtures

\subsection{Photochemical Studies}

\subsubsection{Singlet Oxygen Quantum Yield $\left(\Phi_{\Delta}\right)$}

To a $1 \times 10^{-5} \mathrm{M}$ zinc complex of $\mathbf{4 a}$ in DMSO was added 1,3-Diphenylisobenzofuran (DPBF) for singlet oxygen quantum yield measurement as an extinguisher in dark. An $8.15 \times 10^{15}$ photon $\mathrm{s}^{-1} \mathrm{~cm}^{-2}$ was sent to the mixture every 10 seconds. The changes in absorption at $417 \mathrm{~nm}$ were then observed (Figure 7). A decrease of B band was observed. The calculated $\boldsymbol{\Phi}_{\Delta}$ was found to be high compare with the literature ${ }^{30}$ (Table 5). These results indicated that $\mathbf{4 a}$ could be used as a photosensitizer in PDT applications.

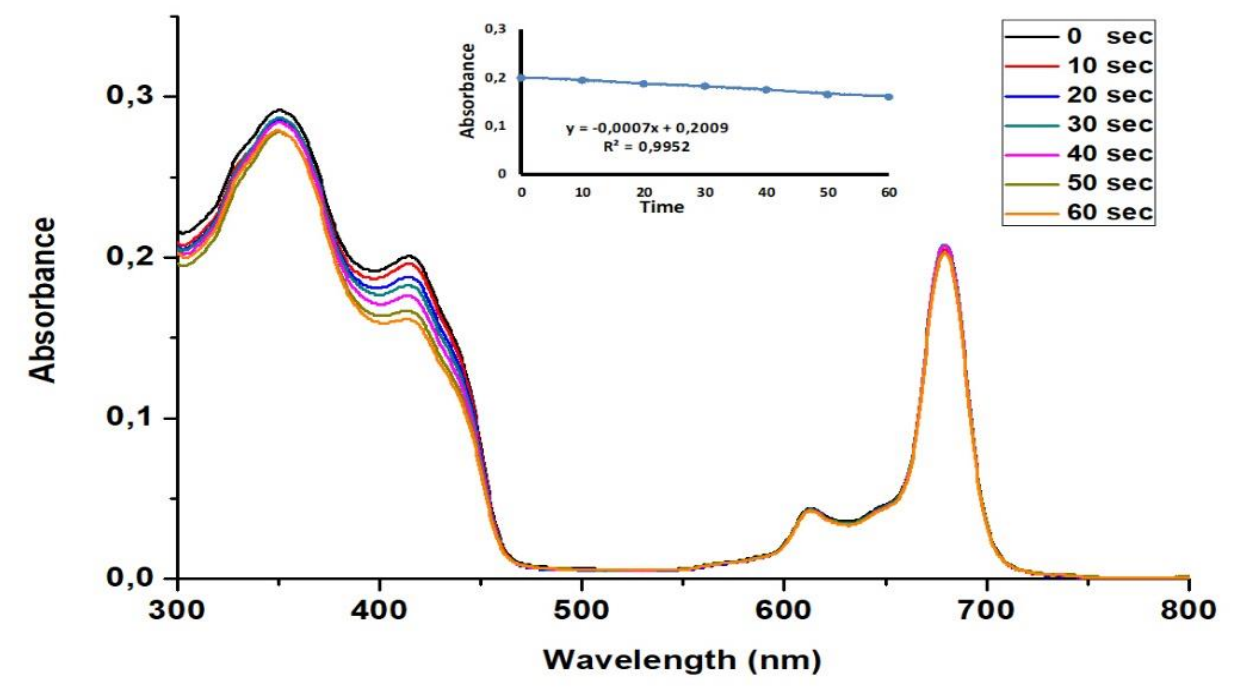

Figure 7. A typical spectrum for the determination of singlet oxygen quantum yield of $\mathbf{4 a}$ in DMSO using DPBF as the singlet oxygen quencher. Concentration $=1 \times 10^{-5} \mathrm{~mol} \mathrm{dm}^{-3}$.

(Inset: plots of DPBF absorbance vs. time)

\subsubsection{Photodegradation and Quantum Yield $\left(\Phi_{d}\right)$}

Production of singlet oxygen begins with absorption of a photon at 290-700 nm. Energy of this photon is then transmitted to the electrons in the molecule by converting it to a singlet oxygen, a 
highly reactive form of triplet oxygen. While the molecule is transformed from its basic state into an excited state, it causes formation of functional groups (carbonyl, carboxyl, peroxide, etc.) and new conjugated bonds as well as configuration changes (dehydrogenation, demethylation, dehydromethylation) in the molecule. Moreover, when phthalocyanines are exposed to photons, different reactions may form. If a phthalocyanine contains an acceptor group, it is hardly oxidized, thus, photodegradation reaction slows down.

The compound 4a, in DMSO, was exposed to UV-Vis light at $682.5 \mathrm{~nm}$ for photodegradation. Then, quantum yield in a specific time interval of $3.26 \times 10^{16}$ photon $\mathrm{s}^{-1} \mathrm{~cm}^{-2}$, and the changes in the $\mathrm{Q}$ band were examined (Figure. 8). During the photodegradation measurements $\mathrm{Q}$ band was observed to decrease over time, i.e. measured every 5 minutes. In line with the literature reports, both photodegradation and quantum yield values of $\mathbf{4 a}$ increased (Table 5). ${ }^{33}$ The compounds having photodegradation values in the range of $10^{-3}$ to $10^{-6}$ are not considered to be stable, according to the literature.

Table 5. Photochemical parameters of $\mathbf{4 a}$ in DMSO

\begin{tabular}{lcc}
\hline Compound & $\boldsymbol{\Phi}_{\boldsymbol{\Delta}}$ & $\boldsymbol{\Phi}_{\mathbf{d}}$ \\
\hline $\mathbf{4 a}$ & 0.80 & $5.7 \times 10^{-4}$ \\
$\mathrm{ZnPc}^{\mathrm{a}}$ & 0.67 & $2.6 \times 10^{-5}$ \\
\hline
\end{tabular}

${ }^{\text {aData from Ref. }}{ }^{39}$

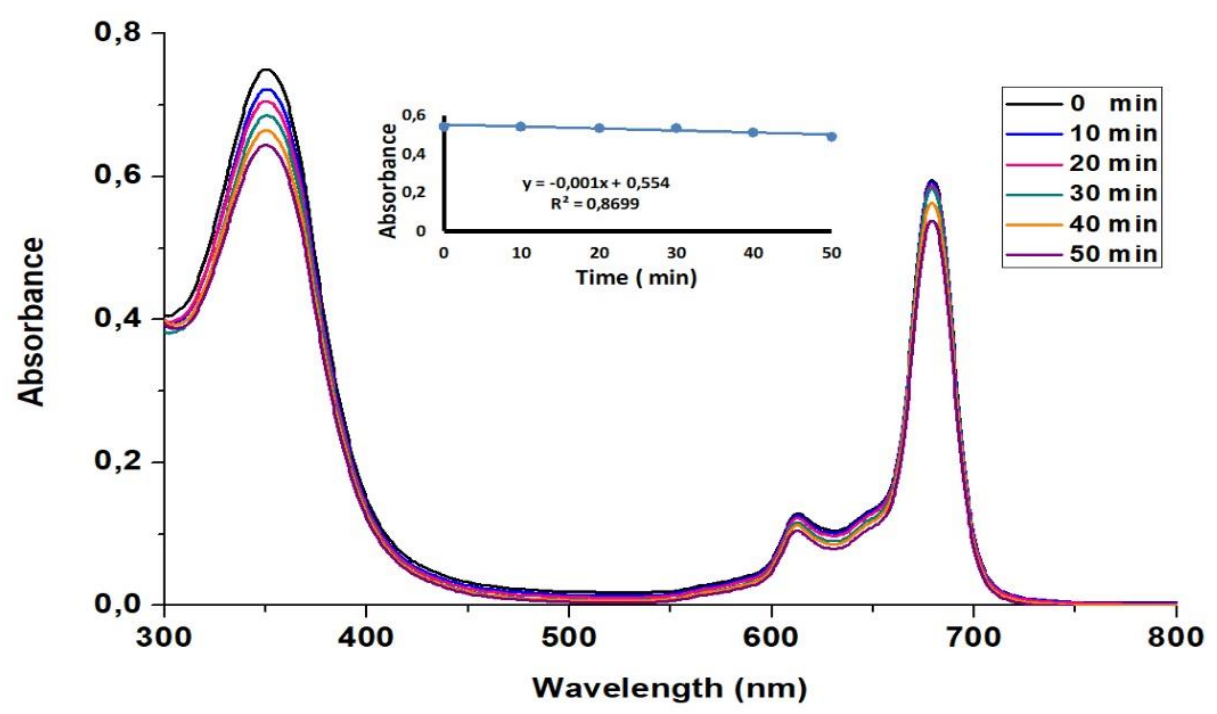

Figure 8. The photodegradation of $4 \mathbf{a}$ in DMSO showing the disappearance of the $\mathrm{Q}$ band and the appearance of the reduction band from $0 \mathrm{~min}$ to $50 \mathrm{~min}$ (Inset: plot of $\mathrm{Q}$ band absorbance versus time)

\section{Conclusions}

In this study, two new phthalocyanines, substituted with chalcone bearing conjugated phenyloxy group, designed, synthesized and characterized. The starting material, 4(benzyloxy)benzaldehyde 1, was prepared from 4-hydroxy benzaldehyde and benzyl chloride in the presence of $\mathrm{K}_{2} \mathrm{CO}_{3}$ in DMF. In the second step, 4-(benzyloxy)benzaldehyde and 4hydroxyacetophenone were reacted using $\mathrm{SOCl}_{2}$ in absolute ethanol to give (E)-3-(4(benzyloxy)phenyl)-1-(4-hydroxyphenyl)prop-2-en-1-one 2. The nucleophilic substitution reaction between compound $\mathbf{2}$ and 4-nitrophthalonitrile were afforded compound $\mathbf{3}$ in DMF using potassium carbonate as the third step. Then $\mathrm{ZnPc} \mathbf{4 a}$ and $\mathrm{CoPc} \mathbf{4 b}$ were obtained as soluble compounds in good yields. Their photophysical and photochemical properties were investigated along with their biological and metal chelating effects and DPPH radical scavenging assays. 


\section{Conflict of interest}

The authors confirm that this article content has no conflict of interest.

\section{Acknowledgments}

This work was supported, with Grand No: TBAG-113Z699, KBAG-115Z446, and 217Z043 by Scientific and Technological Research Council of Turkey (TUBITAK) respectively. Therefore, the authors are grateful for carrying out this research with the help of TUBITAK.

\section{ORCID}

Arif Baran: 0000-0002-4117-5099

Emel Karak1lıç: 0000-0002-8447-2851

Özlem Faiz: 0000-0003-2447-0763

Furkan Özen: 0000-0002-4703-0333

\section{References}

[1] Claessens, C. G.; Hahn, U.; Torres, T. Phthalocyanines: From outstanding electronic properties to emerging applications. Chem. Record, 2008, 8, 75-97.

[2] Çakır, D.; Arslan, T.; Bıyıklığlu, Z. Effect of substituent position and metal type on the electropolymerization properties of chalcone substituted metallophthalocyanines. Dalton Transaction. 2015, 44(48), 20859-20866.

[3] Saka, E. T.; Çelik, G.; Sarkı, G.; Kantekin, H. Symmetrical and difunctional substituted cobalt phthalocyanines with benzoic acids fragments: Synthesis and catalytic activity J. Incl. Phenom. Macrocycl. Chem. 2016, 85, 161-168.

[4] Stavric, B. Role of chemopreventers in human diet Clin. Biochem. 1994, 27(5), 319-332.

[5] Lu, J.; Wang, C. Medicinal components and pharmacological effects of Rosa rugosa.Rec.Nat.Prod. 1994, 12, 535-543.

[6] Çarıkçı, S.; Kılıç, T.; Özer, Z.; Dirmenci, T.; Arabaci, T.; Gören, A.C. Quantitative determination of some phenolics in Origanum laevigatum Boiss. extracts via validated LC-MS/MS method and antioxidant activity. J.Chem.Metrol. 2018, 12, 121-127.

[7] Miller, J. D.; Baron, E. D.; Scull, H.; Hsia, A,; Berlin, J. C.; McCormick, T,; Colussi, V.; Kenney, M. E.; Cooper, K. D.; Oleinick. N. L. Photodynamic therapy with the phthalocyanine photosensitizer Pc 4: The case experience with preclinical mechanistic and early clinical-translational studies. Toxicol. Appl. Pharmacol. 2007, 224(3), 290-299.

[8] Bacellar, I. O. L.;Tsubone, T. M.; Pavani, C.; Baptista, M. S. Photodynamic efficiency: From molecular photochemistry to cell death. Int. J. Mol. Sci. 2015, 16(9), 20523-20559.

[9] Dougherty, T. J.;Charles J. G.; Henderson B. W.; Jori, Giulio.; D, Kessel.; Korbelik, M.; Moan J.; Qian, P. Photodynamic therapy. J. Nat. Cancer Inst. 1998, 90(12), 889-905.

[10] O’Connor, A. E.; Gallagher, W. M.; Byrne, A. T. Porphyrin and nonporphyrin photosensitizers in oncology: Preclinical and clinical advances in photodynamic therapy. Photochem. Photobiol. 2009, 85, 1053-1074.

[11] Manashi, B.; Milnes, M.; Williams, C.; Balmoori, J.; Ye, X.; Stohsand, S.; Bagchi, D. Acute and chronic stress-induced oxidative gastrointestinal injury in rats, and the protective ability of a novel grape seed proanthocyanidin extract. Nutr. Res. 1999, 19(8), 1189-1199.

[12] Yıldız, S. Z.; Küçükislamoglu, M.; Tuna, M. Synthesis and characterization of novel flavonoidsubstituted phthalocyanines using (土)naringenin. J. Organomet. Chem. 2009, 694, 4152-4161.

[13] Acar, I.; Arslan, T.; Topçu, S.; Serkan, A. A.; Şen, S.; Serencam, H. Synthesis and electrochemistry of metallophthalocyanines bearing $\{4-[(2 \mathrm{E})-3-(3,4,5$-trimethoxyphenyl)prop-2-enoyl]phenoxy $\}$ groups. $J$. Organomet. Chem. 2014, 752, 25-29.

[14] Formica, J. V.; Regelson, W. F. Review of the biology of quercetin and related bioflavonoids. Chem Toxicol. 1995, 33(12), 1061-1080.

[15] Alberto, M. E.; De Simone, B. C.; Mazzone, G.; Sicilia, E. Heavy atom effect on Zn(II) phthalocyanines derivatives: a theoretical exploration of the photophysical properties. Phys. Chem.Phys. 2015, 17, 23595.

[16] Dumoulin, F.; Durmus, M.; Ahsen, V.; Nyokong, T. Synthetic pathways to water-soluble phthalocyanines and close analogs. Coord. Chem. Rev. 2010, 254, 2792-2847.

[17] Mori, GD.; Fu. Z.; Viola, E.; Cai, X.; Ercolani, C.; Donzello, M.P.; Kadish, K. M. Tetra-2,3pyrazinoporphyrazines with externally appended thienyl rings: Synthesis, UV-visible spectra, 
electrochemical behavior, and photoactivity for the generation of singlet oxygen. Inorg. Chem. 2011, 50, 8225-8237.

[18] Cong, F.; Wei, Z.; Huang, Z.; Yu. F.; Liu, H.; Cui, J.; Yu, H.; Chu, X.; Du, X.; Xing, K.; Lai, Characteristic absorption band split of symmetrically tetra-octyloxy metal phthalocyanines. J. Dyes Pigment. 2015, 120, 1-7.

[19] Fandakli, S.; Doğan, S.; Sellitepe, H.E.; Yaşar, A.; Yaylı N. Synthesis, theoretical calculation and $\alpha-$ glucosidase inhibition of new chalcone oximes. Org.Commun. 2018, 215, 23-34.

[20] Ivanova, Y.; Gerova, M.; Petrov, O. $\mathrm{SOCl}_{2} / \mathrm{EtOH}$ : Catalytic system for synthesis of chalcones. Catal. Commun. 2008, 9, 315-316.

[21] Kantar, G. K.; Faiz, Ö.; Sahin, O.; Sasmaz, S. Phthalocyanine and azaphthalocyanines containing eugenol: synthesis, DNA interaction and comparison of lipase inhibition properties. J. Chem. Sciences 2017, 129, 1247-1256.

[22] Li, M.; Pare, P.W.; Zhang, J.; Kang, T.; Zhang, Z.; Yang, D.; Wang, K.; Xing, H. Antioxidant capacity connection with phenolic and flavonoid content in Chinese medicinal herbs. Rec. Nat. Prod. 2018, 12, $239-250$.

[23] Halfon, B.; Çetin, Ö.; Kökdil, G.; Topçu, G.Chemical investigation and bioactivity screening of Salvia cassia extracts. Rec. Nat. Prod. 2019, 13, 156-166.

[24] Baran, A.; Çol, S.; Karakılıç, E.; Özen, F. Photophysical, photochemical and DNA binding studies of prepared phthalocyanines. Polyhedron 2020, 175, 114205.

[25] Pavithra, K.; Vadivukkarasi, S. Evaluation of free radical scavenging activity of various extracts of leaves from Kedrostis foetidissima (Jacq.) Cogn.Food Sci. Human Wellnes. 2015, 4 (1), 42-46.

[26] Kauthale, S.; Tekale, S.; Damal, M.; Sangshetti, J.; Pawar, R. Synthesis, antioxidant, antifungal, molecular docking and ADMET studies of some thiazolyl hydrazones. Bioorg. Med. Chem. Lett. 2017, 27(16), 3891-3896.

[27] Zhou, D.Y.; Sun, Y. X.; Shahidi, F. Preparation and antioxidant activity of tyrosol and hydroxytyrosol esters. J. Funct. Foods 2017, 37, 66-73.

[28] Carter, P. Spectrophotometric determination of serum Iron at the submicrogram level with a new reagent (Ferrozine). Anal. Biochem. 1971, 40 (2), 450-458.

[29] Blois, M.S. Antioxidant determination by the use of a stable free radical. Nature 1958, 181, 1199-1200.

[30] Chamarthi, N.R.; Ponne, V.C.; Pulluru, H.B.; Balija, J.D.; Gutala, S.R.; Kallimakula, S.V.; Chintha, V.; Wudayagiri, R..New symmetrical acyclic and alicyclic bisurea derivatives of 4,4'- methylenebis(phenyl isocyanate): Synthesis, characterization, bioactivity and antioxidant activity evaluation and molecular docking studies. Org.Commun. 2018, 11, 80-97.

[31] Brannon, J.H. Picosecond laser photophysics. Group 3A phthalocyanines. J. Am. Chem. Soc. 1980, 102, 62-65.

[32] Seotsanyana, M. I.; Kuznetsova, N.; Nyokong, T. Photochemical studies of tetra-2,3pyridinoporphyrazines. J. Photochem. Photobiol. A Chem. 2001, 140, 215-222.

[33] Spiller, W.; Kliesch, H.; Worhle, D.; Hackbarth, S.; Roder, B.; Schnurpfeil, G. Singlet oxygen quantum yields of different photosensitizers in polar solvents and micellar solutions. J. Porphyr. Phthal. 1982, $145-158$.

[35] Bayrak, R.; Akçay, H.T.; Pişkin, M.; Durmuş, M.; Değirmencioğlu, I. Azine-bridged binuclear metallophthalocyanines functioning photophysical and photochemical-responsive. Dyes Pigment. 2012, 95, 330-337.

[36] Nyokong, T. Effects of substituents on the photochemical and photophysical properties of main group metal phthalocyanines. Coord. Chem. Rev. 2007, 251, 1707-1722.

[37] Ogunsipe, A.; Nyokong, T. Photophysical and photochemical studies of sulphonated non-transition metal phthalocyanines in aqueous and non-aqueous media J. Photochem. Photobiol. A Chem. 2005, 173, $211-$ 220.

[38] Darwent, J. R.; Douglas, P.; Harriman, A.; Porter, G.; Richoux, M. Metal phthalocyanines and porphyrins as photosensitizers for reduction of water to hydrogen. Coord. Chem. Rev. 1982, 44, 83-126.

[39] Zagal, J. H.; Gulppi, M, A.; Cardenas-Jiron, G. Metal-centered redox chemistry of substituted cobalt phthalocyanines adsorbed on graphite and correlations with MO calculations and Hammett parameters. Electrocatalytic reduction of a disulfide. Polyhedron 2000, 19, 2255-2260.

[40] Somakala, K.; Amir, M.; Sharma, V.; Wakode, S. Synthesis and pharmacological evaluation of pyrazole derivatives containing sulfonamide moiety. Monatsh. Chem. 2016, 147, 2017-2029.

[41] Shinohara, H.; Tsaryova, O.; Schnurpfeil, G.; Wöhrle, D. Differently substituted phthalocyanines: Comparison of calculated energy levels, singlet oxygen quantum yields, photo-oxidative stabilities, photocatalytic and catalytic activities differently substituted phthalocyanines: Comparison of calculated energy levels, singlet oxygen quantum yields, photo-oxidative stabilities, photocatalytic and catalytic activities. J. Photochem. Photobiol. A Chem. 2006, 184, 50-57. 
[42] Ozcesmeci, M.; Ozcesmeci, I.; Hamuryudan, E. Synthesis and characterization of new polyfluorinated dendrimeric phthalocyanines. Polyhedron 2010, 29, 2710-2715.

[43] Hamuryudan, E.. Synthesis and solution properties of phthalocyanines substituted with four crown ethers. Dyes Pigment. 2006, 2-3, 151-157.

[44] Durmus, M.; Nyokong, T.; Synthesis and solution properties of phthalocyanines substituted with four crown ethers. Polyhedron 2007, 26, 2767-2776.

[45] Engelkamp, H.; Nolte, R. J. M. J. Doctoral thesis. Porphyrins Phthal. 2000, 4, 454.

[46] Kobak, R. Z. U.; Gul, A. Synthesis and solution studies on azaphthalocyanines with quaternary aminoethyl substituents. Color Technol. 2009, 125, 22-28.

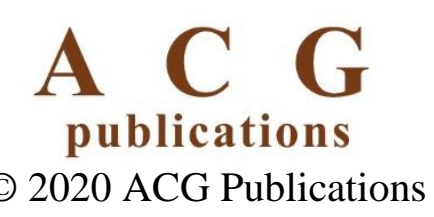

